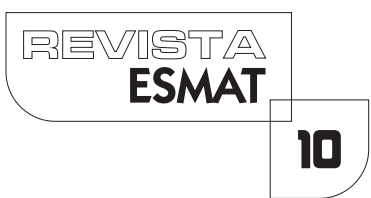

\title{
O ENCARCERAMENTO FEMININO À LUZ DOS DIREITOS HUMANOS
}

FEMALE IMPRISONMENT FROM THE PERSPECTIVE

OF HUMAN RIGHTS

Cleide Leite de Sousa dos Anjos

Acadêmica do Mestrado Profissional Multidisciplinar em Prestação Jurisdicional e Direitos Humanos, realizado em parceria com o Tribunal de Justiça do Estado do Tocantins e a Universidade Federal do Tocantins.

Luíza Maria Rodrigues

Acadêmica do Mestrado Profissional Multidisciplinar em Prestação Jurisdicional e Direitos Humanos, realizado em parceria com o Tribunal de Justiça do Estado do Tocantins e a Universidade Federal do Tocantins.

\section{RESUMO}

No escopo deste artigo sobre o encarceramento feminino à luz dos direitos humanos brasileiro, de acordo com as estatísticas da Infopen, de 20 I 4, o Brasil contou com uma população de 579.78 I I pessoas custodiadas no Sistema Penitenciário Brasileiro, sendo 37.380 mulheres e 542.40 I homens. Ao longo deste trabalho, ficou claro que a transgressão à lei confere ao Estado o direito de punir, e que esta é aplicada de acordo com as normas jurídicas vigentes, com a diminuição ou perda dos bens jurídicos, sendo ao réu aplicados os efeitos de uma sentença e, ao mesmo passo, uma obrigação, devendo submeter-se. Assim, tem-se que a pena é vista como uma forma de defender a sociedade que se encontra organizada juridicamente contra os perigos ou ameaças por parte do delinquente, neste caso específico as presas mulheres. Embora muitos preguem a necessidade de maior rigidez do ordenamento jurídico, especialmente no que se refere à aplicação de leis mais severas, tanto para a aplicação da pena, quanto na execução desta. Todavia, não há dúvida de que a legislação penal pátria é bastante severa, porém necessita de que a sua aplicação e acompanhamento se deem de maneira correta por parte do Poder Público. A metodologia utilizada foi o método bibliográfico.

PALAVRAS-CHAVE: Encarceramento feminino; Direitos humanos; Legislação. 


\begin{abstract}
In the scope of this article on the female incarceration in the light of Brazilian human rights, according to the statistics InfoPen 2014, Brazil had a population of 579.78 I I people in custody in the Brazilian prison system, and 37,380 women and 542,40 I men. Throughout this work it became clear that the transgression of the law gives the state the right to punish, and that it is applied in accordance with the applicable legal rules, with the reduction or loss of legal goods, and the defendant applied the effects of a sentence and at the same step, a must, must submit. So it is that the penalty is seen as a way of defending society that is legally organized against the dangers or threats by the offender, in this particular case the arrested women. While many preach the need for greater rigidity of the law, especially as regards the application of more stringent laws, both for the application of the sentence, and the execution thereof. However, there is no doubt that the criminal law country is quite severe, but requires that its implementation and monitoring correctly, by the Government.
\end{abstract}

KEYWORDS: Female incarceration; Human rights; Legislation.

\title{
I INTRODUÇÃO
}

Cotidianamente, o Brasil é bombardeado com uma série de noticiários sobre fugas, rebeliões, massacres, pessoas mantidas como reféns nas mãos de criminosos, corrupção dos diretores, agentes penitenciários e policiais.

A privação da liberdade, por si só, representa um grande castigo para o ser humano. Mas não pode agravar-se pelos maus-tratos, em função do problema da superpopulação carcerária, falta de higiene, de trabalho, carência médica, jurídica, abusos sexuais e outras violências. Nesse sentido, é observado que o encarceramento feminino à luz dos direitos humanos fere os dispositivos constitucionais.

O presente estudo, por meio das pesquisas bibliográficas, visa demonstrar que o encarceramento feminino à luz dos direitos humanos é um problema fático, pois, além de infringir os direitos individuais, observa-se que os maiores problemas do sistema penitenciário no mundo e no Brasil são exatamente os resultados alcançados, os expresidiários saem pior do que entram e voltam a delinquir, na maioria das vezes, com maior frequência.

Quando tentam se readaptar são barrados, ficam à margem da sociedade sofrendo discriminações. A privação da liberdade, temporária ou definitiva, é, por si só, uma pena a que ninguém é indiferente, porque representa o maior castigo para um ser humano. Mas não pode ser agravada pelas condições precárias que o sistema prisional proporciona ao seu cumprimento. 
O sistema penitenciário deveria objetivar a recuperação desses indivíduos, neste caso específico, as mulheres encarceradas; no entanto, o único resultado útil que se alcança, pelo menos aqui no Brasil, é o afastamento temporário da infratora.

A ociosidade permanente em ambiente de promiscuidade junta as presas primárias, que cumprem uma pequena pena, às criminosas condenadas a longos anos de reclusão, e as reúne num mesmo ambiente limitado e desqualificado, a ponto de ser desumano, o que gera consequências imprevisíveis, muitas vezes irreparáveis.

$\bigcirc$ Código Penal Brasileiro, ao tipificar as condutas delituosas cominando-lhes as penas, busca reprimir as ações nocivas à sociedade, quer praticadas individual ou coletivamente, quer praticadas passional ou de forma planejada e organizada.

$\bigcirc$ Código de Processo Penal traz, em seu interior, uma gama de medidas procedimentais e processuais, conferindo mais agilidade às forças judiciais e de segurança pública no enfrentamento às ações delituosas, tendo o legislador infraconstitucional adotado o cuidado de adequar a Legislação Processual Penal à Constituição Federal.

A sociedade como um todo, desde os seus primórdios, encontra-se em constante evolução, nas mais diversas esferas, como a econômica, política, social, moral, dentre outras, fazendo com que surjam novos fatos nesses novos universos, formação de conflitos e necessidade de mudanças que devem acompanhar e se moldar a essa nova realidade. Assim, a criminologia, como ciência, trabalha na observação e análise dos fatos no universo do crime, para melhor compreensão, entendimento e objetivando a prevenção eficaz no tratamento da problemática criminal no meio social.

Quanto à metodologia empregada, apesar do caráter universal de estruturação lógica e de organização metodológica, os trabalhos científicos diferenciam-se em função principalmente de seus objetivos e da natureza do próprio objeto abordado, assim como em função de exigências específicas de cada área do saber humano. Assim, este trabalho teve como método o dedutivo e a pesquisa bibliográfica atinente ao tema.

A par disso, este artigo traz à tona o encarceramento feminino à luz dos direitos humanos, como pode ser observado nas próximas páginas.

\section{O ENCARCERAMENTO FEMININO À LUZDOS DIREITOS HUMANOS}

\section{I Evolução do sistema penitenciário no mundo}

Entende-se por sistema penitenciário atual o conjunto de recursos e normas que regulam a execução das penas privativas de liberdade, diferentemente do que era visto até meados do século XVII, em que predominavam os suplícios e as penalidades corporais, os quais Michel Foucault retrata de maneira explícita: 
Damiens [fora condenado, a 2 de março de 1757], a pedir perdão publicamente diante da porta principal da Igreja de Paris [aonde devia ser] levado acompanhado numa carroça, nu, de camisola, carregando uma tocha de cera acesa de duas libras; [em seguida], na dita carroça, na praça de Greve, e sobre um patíbulo que aí será erguido, atenazado nos mamilos, braços, coxas e barrigas das pernas, sua mão direita segurando a faca com que cometeu o dito parricídio, queimada com fogo de enxofre, e às partes em que será atenazado se aplicarão chumbo derretido, óleo fervente, piche em fogo, cera e enxofre derretidos conjuntamente, e a seguir seu corpo será puxado e desmembrado por quatro cavalos e seus membros e corpo consumidos pelo fogo, reduzidos a cinzas, e suas cinzas lançadas ao vento. (2010, p. 09)

Em meados do século XVI, começou-se a implantação das penas privativas de liberdade, como mencionam Kloch e Motta. O primeiro estabelecimento de prisão foi fundado, em 1552, em Londres, e era chamado House of Correction de Bridwell, destinado, sobretudo, ao recolhimento de vagabundos, tinha aspecto de estabelecimento de segurança, e os presos eram obrigados a trabalhar. Depois disso, outras casas de trabalho foram fundadas nas cidades mais importantes, como em Amsterdã, em 1559, com prisões para homens e mulheres; Bremen, em 1609; e Hamburgo, em I 662, e se espalharam pelo mundo. (KLOCH; MOTTA, 2008)

Pode-se citar, ainda, o Sistema Pensilvânico, também conhecido como prisão celular, que forneceu as bases filosóficas para o sistema penitenciário atual, em 1682, na Pensilvânia era estabelecido que a maioria dos crimes iriam ser punidos com a força de trabalho forçado e pelas penas privativas de liberdade em substituiç̧ão aos castigos físicos e as mutilações, já a pena de morte foi limitada a crimes de homicídio. E foi lá também na Pensilvânia que as prisões começaram a ser chamadas de penitenciárias; este modelo era conhecido como regime Filadélfia. (FOUCAULT, 2010)

Segundo Kloch e Motta, o modelo ficou conhecido como "A prisão que adotou o isolamento dos apenados", pois, não podiam se comunicar e eram obrigados a cultuar a religião, isolamento este que apenas contribuía para que os condenados atingissem a loucura ou se suicidassem. (2008, p. 28)

Em I 8 6, surgiu o sistema Auburniano, da cidade de Alburn, em New York, com o intuito de reformar o sistema Pensilvânico, neste sistema os presos trabalhavam juntos durante o dia em silêncio e eram isolados à noite. No entanto, este sistema também surgiu com intuito de aproveitar a mão de obra penitenciária como força produtiva ao regime político-econômico adequando-a ao sistema capitalista vigente.

O sistema Pensilvânico buscava a transformação do delinquente por meio do arrependimento, levado pela reflexão religiosa. Já o sistema Auburniano corrigia o apenado pelo trabalho e pela disciplina; no entanto, foram bastante criticados pela ausência de humanização e ressocialização dos apenados.

Assim, o que se pode perceber é que o sistema Pensilvânico baseava-se na religião, e o Auburniano claramente em motivações econômicas. Vale ressaltar que o 
sistema Auburniano, anos depois, mais precisamente em 1840, foi substituído pelo sistema penitenciário Progressivo porque a mão de obra penitenciária começou a competir com o trabalho livre, tornando-se um impasse para a economia. $(\mathrm{KLOCH}$; MOTTA, 2008)

Destarte, o sistema penitenciário progressivo surgiu com a necessidade de reabilitação dos penitenciários e a substituição dos trabalhos forçados, objetivando, com isso, uma reforma moral e uma boa conduta do recluso para sua vida em sociedade. A divisão desse sistema ocorria em três períodos diferentes: no primeiro, a reclusão celular diurna e noturna, onde o preso era isolado 24 horas, para que refletisse sobre o seu comportamento criminoso; na segunda fase, reclusão celular noturna e trabalho diurno, este ocorria silenciosamente durante o dia e o isolamento durante a noite; finalmente, na última fase, o preso adquiria liberdade condicional e, caso não houvesse revogação, liberdade definitiva. (FOUCAULT, 20 I0)

Comenta José Frederico Marques que

[...] A utilização das prisões como instrumento de punição, nos tempos em que se antecederam ao movimento humanista do século XVIII, revertia-se das mesmas totalidades rudes e bárbaras, iníquas e desumanas dos castigos então impostos pelas legislações penais das monarquias absolutistas. (2006, p. I34)

Foi então que na idade moderna se iniciou um movimento que desenvolveu o real conceito de pena privativa de liberdade, criando, nessa época, prisões para a correção dos apenados. E então, a partir do século XVIII, começaram a se formar as raízes do sistema penitenciário, em que, por muito tempo, o condenado foi apenas objeto da execução penal, e assim, de modo recente, foram reconhecidos os direitos da pessoa humana do condenado. Reiterando, contudo, o direito penitenciário que ressaltou a proteção ao condenado, sendo que esse direito se baseia na ética de respeitar a dignidade do homem como pessoa moral.

E seguindo a discussão sobre a criação das prisões, Odete Maria de Oliveira afirma que

[...] Foi na sociedade cristã que a prisão tomou forma de sanção. De inicio foi aplicada temporariamente e, após como detenção perpetua em celular', nascida no século $V$, teve inicialmente aplicações a pena de morte. Daí encarcerar os valores da segregação que favorecia a penitenciária. $\bigcirc$ encarecimento da cela, denominado "in pace", deu origem à chamada prisão celular, nome que a bem poço tempo era usado na legislação penal. (2003, p. 49)

castigo, seguindo a linha dos nietzshiano, é um instrumento de difícil definição, porque possuem vários sentidos e propósitos que, embora se amoldem ao tempo e ao espaço em que estão inseridos, carregam no bojo nuances históricas. (NIETZSCHE, 1988, p. 47) 
Há indícios de que as primeiras penitenciárias foram criadas no século XVI e tinham a finalidade de correção. Augusto Thompson cita como exemplo a "House of Correction" (Casa de Correção), em Londres, construída entre 1550 e 1552; a Prisão de Nuremberg, em I 558; a Prisão de Amsterdã para homens, em I 595, e para mulheres, em 1597 que foi construída por protestantes. No século XVIII, surgiram as primeiras e modernas penitenciárias, como: "Instituto de São Miguel, em Roma, construído por ordem do Papa Clemente e Casa de correção de Gand, na Bélgica no ano de 1775". ( 1980, p. I I I)

Foi então que na idade moderna se iniciou um movimento que desenvolveu o real conceito de pena privativa de liberdade, criando, nessa época, prisões para efetiva correção dos apenados.

Desse modo, nota-se que a prisão é menos recente do que se diz datar seu nascimento dos novos códigos. (FOUCAULT, 20 I0, p. 217)

\subsection{O surgimento da prisão como medida punitiva}

\subsection{A prisão no Brasil}

Código Brasileiro Criminal, em meados de 1830, regulamentou as penas de trabalho e prisão. A primeira prisão no Brasil foi inaugurada em 1850 e recebeu o nome de Casa de Correição de Corte, atualmente conhecida como complexo Frei Caneca, no Rio de Janeiro.

Roberto Porto contextualiza dizendo:

O encarceramento penal, desde a sua origem visava, ao mesmo tempo a privação da liberdade e a transformação dos indivíduos. A ideia do uso do tempo para medir o castigo sempre esteve ligada à igualdade, já que a liberdade é um bem que pertence a todos da mesma maneira. Reiterando a liberdade do condenado, a prisão traduz a ideia de lesão não somente a vítima, mas a toda a sociedade. (2008, p. 13)

Dando seguimento, a punição se sujeita aos possíveis danos à ordem social que o crime pode ocasionar, e não aos danos materiais propriamente ocorridos. A punição e o sistema carcerário estão presentes de tal maneira no social que passou a ser considerado legítimo aquele que pune, deixando de ser indecoroso o castigo, fazendo com que ambos caminhem juntos e edifiquem os presídios aonde a punição "legal" venha acompanhada dos castigos "extralegais" (PASSETI, 20 I 4).

As penas que privam a liberdade completam, portanto, a última fase da cadeia evolutiva das penas, deixando para trás a fase das penas cruéis que existiam na idade média. No caso do Brasil, as penas cruéis eram previstas nas Ordenações Portuguesas (BOSCHI, 2008, p. 95). 
Edmundo Oliveira comenta o quão importante é a prisão e sua evolução como medida de punição:

De qualquer modo, o fato é que hoje em dia não podemos passar sem ela. A quem pretenda infligir à lei é preciso oferecer um contraestímulo, um motivo para não fazê-lo. O grande lamento é que a prisão continua a se apresentar como um espetáculo deprimente, atingindo além da pessoa do delinquente: orfana filho de pai vivo, enviúva a esposa de marido combalido, prejudica o credor preso tornando-o insolvente, desadapta o encarcerado à sociedade, suscita graves conflitos sexuais, onera o Estado, amontoa seres humanos em jaulas sujas, úmidas onde vegetam em olímpica promiscuidade. (2003, p. 07).

Por fim, no entendimento de Oliveira (2003), é notório o fato de que a prisão é indispensável à sociedade, e quem resolver cometer qualquer tipo de ilicitude deverá estar sujeito às suas condições, porém, devem-se oferecer, de certo modo, motivos explícitos para que o apenado que cometeu o crime aprenda com o seu erro, e aquele que ainda não cometeu não o faça.

\subsection{Sistema penitenciário brasileiro}

Anteriormente, no Brasil, eram aplicadas formas cruéis de tortura e agressão para que os presos fossem obrigados a confessar seu crime, pois, na época, estes não poderiam ser condenados à execução pública antes desse procedimento. Esse sistema punitivo que vigorou até o final do Século XVII, baseado em suplícios e castigos corporais, foi substituído com a privação da liberdade, reclusão do condenado, apresentando-se assim uma forma de prisão mais humana.

Quando se fala em sistema penitenciário vem à mente a palavra prisão, nesse sentido, "A prisão, em sentido jurídico, é a privação da liberdade de locomoção, ou seja, do direito de ir e vir, por motivo ilícito ou por ordem legal" (MIRABETE, 2007, p. 388).

Para Fernando Capez, a prisão "É a privação da liberdade de locomoção determinada por ordem escrita da autoridade competente ou em caso de flagrante delito" (2009, p. 244).

De outro modo, Costa Neto é enfático ao dizer que,

Atualmente, diversas são as críticas a respeito da situação carcerária brasileira, alguns falam inclusive na falência do sistema carcerário, e muitas são as discussões acerca da sua eficácia. A precariedade das instituições carcerárias e as condições subumanas nas quais vivem os presos colocam em xeque o objetivo ressocializador da pena privativa de liberdade, gerando questionamentos quanto à possibilidade de obtenção de efeitos positivos do cárcere sobre o apenado. (2013, online) 
Segundo o pensamento de Fernando da Costa Tourinho Filho,

esse conceito abrange as duas espécies de prisão: a prisão como pena, ou prisão sanção, isto é, decorrente de sentença penal condenatória irrecorrível, utilizada como meio de repressão aos crimes e contravenções, e a prisão sem o caráter de pena (2004, p. 390).

Sobre o assunto diz que, "No regime de liberdades individuais que preside nosso direito, a prisão só deveria ocorrer para o cumprimento de uma sentença penal condenatória" (MIRABETI, 2007, p. 389).

Sobre o sistema Penal Brasileiro pode-se dizer, conforme as palavras de Julio Fabrini Mirabete citado por Yvana Savedra de Andrade Barreiros, que

A repressão penal, por vários séculos, foi exercida primordialmente por meio da pena capital, que era, no mais das vezes, executada de forma cruel. E as penas que preservavam o apenado vivo eram demasiadamente cruéis e infamantes (2008, p. 02).

O sistema Prisional Brasileiro segue os princípios do sistema Progressivo Irlandês, com resquícios dos sistemas Pensilvânico e Auburniano, adotados nas penitenciárias, para os condenados ao cumprimento da pena em regime fechado, regime este reservado aos delitos mais graves ou hediondos (BARREIROS, 2008, p. 3).

Assim, Rogério Greco afirma que

Esse raciocínio a respeito da finalidade protetiva de bens jurídicos atribuída ao Direito Penal teve início com Birnbaum, em I 834 antes dele, Feuerbach afirmava que o Direito Penal tinha por fim de proteger direitos subjetivos, pois que o delito significava uma lesão de um direito subjetivo alheio. (2009, p. 05)

Cezar Roberto Bitencourt diz que "A pena é, efetivamente, uma ameaça da lei aos cidadãos para que se abstenham de cometer delitos; é, pois, uma 'coação psicológica' com a qual se pretende evitar o fenômeno delitivo" (2004, p. I I 6).

Segundo Lima (2008, p. 2 I ), "A problemática é imensa, por isso, diversas alternativas são buscadas, mas enquanto não é encontrada uma solução aumenta o número de presídios superpopulosos", podendo, assim, observar a condição em que vivem os encarcerados, pois muitos deles, por falta de leitos, acabam dormindo sentados e até mesmo em pé para que não ocupem espaço em suas celas.

Com tudo isso, nota-se que as prisões não tendem mais a ressocializar os que nelas entram, e sim tornar os indivíduos mais agressivos e revoltados contra a própria sociedade.

De acordo com Denise de Roure apud Patrícia Gomes da Silva, pode-se concluir que "falar em reabilitação é quase o mesmo que falar em fantasia, pois hoje é fato 
comprovado que as penitenciárias em vez de recuperar os presos os tornam piores e menos propensos a se reintegrarem ao meio social" (2008, p. 3 I).

Contudo, existe ainda um grande desconhecimento e desinteresse por parte da sociedade, no que abrange ao Direito Penal Brasileiro quanto os regimes penais e à progressão das penas, pois o preso poderá ir adquirindo aos poucos a sua liberdade.

Fernando Capez explana:

Estado não tem o poder de punir fulano ou beltrano, mas simplesmente tem o poder de punir (qualquer eventual infrator). No momento em que um crime é praticado, esse direito abstrato e impessoal concretiza-se e volta-se especificamente contra 0 delinquente. Nesse instante, de direito passa a pretensão. Pretensão é a disposição de submeter um interesse alheio a um interesse próprio. $\bigcirc$ Estado passa a ter o interesse de submeter o direito de liberdade daquele criminoso ao seu direito de punição. Surge uma relação jurídico-punitiva com o delinquente, pela qual o direito de punir sai do plano abstrato e se concretiza, voltando-se contra o autor da infração penal. (2005, p. 15-16)

É com vistas a cumprir tais objetivos e zelar pela segurança que foram criadas várias legislações que trataram de definir as sanções a serem aplicadas para cada infração cometida.

Considera-se que, em meio às especialidades do direito, a sanção penal negativa encontra-se mais presente no Direito Penal, que, tomando por base o Código Penal (CP) tipifica o ato ilícito e dispõe a pena a ser aplicada a cada caso, o que leva a entendê-la como consequência natural quando se pratica um ilícito penal.

Assim, Fernando Capez manifesta:

É a fase da persecução penal que tem por fim propiciar a satisfação efetiva e concreta da pretensão de punir do Estado, agora denominada pretensão executória, tendo em vista uma sentença judicial transitada em julgado, proferida mediante o devido processo legal, a qual impõe uma sanção penal ao autor de um fato típico e ilícito. (2005, p. 16)

Importante lembrar que o Direito Penal não representa, necessariamente, os elementos e valores morais finais de uma sociedade, visto que se trata de um conjunto de regras que têm por objetivo contribuir para a organização do comportamento social por meio da racionalidade, mesmo que, por certas vezes, vão de encontro com os aspectos que a sociedade considera moralmente repreensível. Porém, noutras, suas regras também se encontram sujeitas a disputas.

Nesse sentido, o Direito Penal pode ser entendido como sendo um conjunto de normas jurídicas, nestas se encontram previstos os crimes e sanções a serem aplicados. Em meio às suas atribuições está a de disciplinar a incidência e validade das normas 
penais, bem como promover e versar acerca da estrutura geral do crime, e, conforme o caso, a aplicação e execução das sanções a serem impostas.

\subsection{O sistema penitenciário brasileiro e as tendências contemporâneas}

O Estado Democrático de Direito que a Constituição oferece ao cidadão tem como vertente o princípio da dignidade da pessoa humana. Os dois juntos buscam uma sociedade mais justa, solidária, com direitos e obrigações iguais para todos.

O sistema penitenciário do País há muito está falido. A situação é precária e as condições em que os encarcerados se encontram hoje, na maioria das vezes, são subumanas, sem falar na violência crescente nas prisões brasileiras.

A superlotação vivenciada hoje nos remete à lembrança de que os presídios no Brasil não passam de meros depósitos de pessoas, e trazem consigo a violência moral, sexual e física entre os detentos. E as consequências logo surgem, basta ver o número alarmante com que as doenças sexuais têm se proliferado entre os detentos, o número de entorpecentes apreendido cada vez maior e a submissão dos mais frágeis ou que tentam levar uma vida normal nos presídios por parte dos mais fortes. As prisões estão abarrotadas e o número de prisões cautelares não para de crescer.

Sabe-se que o sistema penitenciário no Brasil é precário e que o número de detentos, na maioria dos presídios, ultrapassa o número máximo de lotação. Existe também grande quantidade de detentos que oferecem perigo à sociedade e à integridade dos outros presos.

Infelizmente, constata-se que, em muitos casos, a morosidade da justiça faz com que o acusado passe anos na prisão antes de ser absolvido ao final do processo, o que configura um grande número de prisões preventivas ilegítimas.

Olhando pelo lado do acusado, para este a pena sempre será um castigo, mesmo que ainda seja suspensa a execução ou que o condenado seja inocentado. Já para a sociedade em geral, a pena será vista como punição ou forma de intimidar. De outra forma, para a família do acusado, será vista como castigo, mesmo que para a vítima isso sempre soe como vingança.

A Constituição Federal, de 1988, trouxe-nos algumas garantias esculpidas com a finalidade de assegurar aos condenados a dignidade de pessoa humana, a de que eles têm direito e que, por motivo da condenação, fica meio perdida.

A Carta Magna, em seu artigo $5^{\circ}$, nos mostra alguns dos dispositivos que defendem e zelam pela dignidade de pessoa humana do preso:

Art. $5^{\circ}$ - III - ninguém será submetido à tortura nem a tratamento desumano ou degradante;

[...]

XLVII - não haverá penas:

De morte, salvo em caso de guerra declarada, nos termos do art. 84, XIX; 


\section{De caráter perpetuo;}

$[\ldots]$

e) cruéis;

XLVIII - a pena será cumprida em estabelecimentos distintos, de acordo com a natureza do delito, a idade e o sexo do apenado;

XLIX - é assegurado aos presos o respeito à integridade física e moral. (CF/I988)

Na Lei n 7.210, de 1984, a Lei de Execuções Penais (LEP), encontram-se as mais detalhadas normas prisionais do direito pátrio e as principais aspirações do sistema prisional.

Diz o art. 5, XLIX, da Constituição Federal, de 1988, que "é assegurado aos presos o respeito à integridade física e moral", porém o Estado não vem cumprindo com o estabelecido na Carta Magna. Qual seja o motivo, quer por puro descaso do poder público, quer pela inércia da sociedade que sente medo e até insegurança, ou até mesmo pela própria corrupção revelada nas penitenciárias.

O benefício da alimentação constitui-se, também, como prerrogativa básica que o preso tem direito. A alimentação não chega a faltar nos presídios, e as que chegam não são de boa qualidade.

Bom seria se os cidadãos encarcerados tivessem o real tratamento que a Lei ordena, e fosse cumprida a ressocialização, a qual é o grande motivo para restringir a liberdade de ir e vir do acusado.

\subsection{A mulher nos presídios}

Defronte a um sistema prisional construído por homens e para homens, as mulheres enfrentam situações específicas e graves. Essas questões ainda são pouco discutidas pelo poder público e praticamente desconhecidas pela sociedade em geral, uma imensa "fatia" tenta sobreviver.

déficit nas prisões femininas é de cerca de 10 mil vagas, de um total de 467 penitenciárias ou similares informados pelos estados ao Ministério da Justiça, apenas 40 são destinados a mulheres (8,5\%), sendo que apenas 15 (3,2\%) podem ser consideradas penitenciárias de grande porte. É pelo menos 15 unidades femininas no Brasil, o que é pouco diante da massa carcerária feminina, hoje em torno de 25 mil presas. (ABIN, online)

Pelo fato de existirem muitas mulheres detidas em regiões diferentes, onde a cultura, a formação familiar, a formação educacional, a religião, a condição de maternidade, ou não, as muitas estrangeiras, as que possuem relações afetivas fora dos cárceres, as casadas, as que são "laranja", as que são da "turma do vai pra onde o vento sopra", as do crime e as dos crimes mais integrantes de algum partido - "comandos" - fazem com que cada qual passe suas experiências, de forma exclusiva, sendo totalmente pareceres 
pessoais. (MISCIASI, online)

Além do descumprimento da regra constitucional na prática prisional brasileira, decorrem também a discriminação e a opressão da mulher que se encontra encarcerada, conforme explica Castilho:

[...] a prisão para a mulher é um espaço discriminador e opressivo, que se expressa na aberta desigualdade do tratamento que recebe, no sentido diferente que a prisão tem para ela, nas consequências para sua família, na forma como o Judiciário reage em face do desvio feminino e na concepção que a sociedade atribui ao desvio. (2007, p. 42)

Focault descreve o que as prisões podem provocar, dizendo que

muitos autores escreveram sobre as prisões e seus trabalhos apontaram para capacidade que essas instituições têm de provocar, nas pessoas aprisionadas, a desorganização, a desorientação, e até mesmo, a destruição física e psíquica. (FOCAULT, 1997, p. 3 I-32)

As penitenciárias femininas brasileiras ainda apresentam poucas informações, especialmente no que se refere aos danos psicológicos que podem causar as relações estabelecidas entre mãe e filho, bem como no desenvolvimento biopsicossocial de crianças que permanecem nesse ambiente.

\subsection{Mulheres presas em penitenciárias masculinas}

Algumas denúncias mostram que os presidiários do Rio Grande do Norte, Mato Grosso do Sul, Bahia, Pernambuco, Rio de Janeiro e São Paulo apresentam casos de mulheres que são presas dentro de celas com homens, e casos de presídios femininos em que a grande maioria dos funcionários é do sexo masculino.

De acordo com os relatos das presas, muitas vezes elas são obrigadas a manter relações com os presos ou com os funcionários em troca de comida e/ou procuram se relacionar com um preso para evitar a violência de outros. (FOLHA DE SÃO PAULO, online).

Há de se considerar que a prisão, por si só, é um ambiente que favorece a violação de direitos. "O cárcere é uma instituição totalizante e despersonalizadora" e o indivíduo que nele se encontra apresenta ruptura, em diversos níveis, dos vínculos sociais. Não se trata apenas da perda da liberdade, mas da privação por completo da capacidade de autodeterminação. (ESPINOZA, 2004, p. 78)

O Estado do Pará também apresentou um caso que ficou bastante conhecido por meio da mídia, onde uma jovem foi presa numa cela com 20 homens, e ficou cerca de um mês nesta e acabou sofrendo violência sexual, o acontecido foi no interior do Pará, 
na cidade de Abaetetuba ( $137 \mathrm{~km}$ de Belém), não é um fato isolado e exclusivo do Pará. (FOLHADE SÃO PAULO, online).

\subsection{Alguns princípios}

\subsection{Princípio da dignidade da pessoa humana}

Inicialmente, cumpre aqui destacar que a Constituição Federal é a norma que norteia as leis infraconstitucionais. Seguindo esse entendimento, tem-se esta busca à defesa e à valorização do ser humano.

Assim, os direitos e garantias individuais e coletivos, previstos na Constituição Federal, de 1988, oferecem proteção concreta, por meio de normas e princípios nela presentes, como o princípio da dignidade humana.

Ao se falar em dignidade da pessoa humana, faz-se necessário observar o conceito de direitos fundamentais e direitos humanos, composto por critério de união de todos os direitos essenciais aos homens.

Nunes mostra que

A Dignidade da Pessoa Humana não é um direito absoluto, trata-se, portanto, de um princípio que: "identifica um espaço de integridade moral a ser assegurado a todas as pessoas por sua só existência no mundo. É um respeito à criação, independentemente da crença que se professe quanto à sua origem. A dignidade relaciona-se tanto com a liberdade e valores do espírito como com as condições materiais de subsistência. Não tem sido singelo, todavia, o esforço para permitir que o princípio transite de uma dimensão ética e abstrata para as motivações racionais e fundamentadas das decisões judiciais. Partindo da premissa anteriormente estabelecida de que os princípios, a despeito de sua indeterminação a partir de certo ponto, possuem um núcleo no qual operam como regra, tem-se sustentado que no tocante ao princípio da dignidade da pessoa humana esse núcleo é representado pelo mínimo existencial. Embora existam visões mais ambiciosas do alcance elementar do princípio, há razoável consenso de que ele inclui pelo menos os direitos à renda mínima, saúde básica, educação fundamental e acesso à justiça. (2002, p. 102)

Para iniciar o estudo do princípio da dignidade da pessoa humana, faz-se necessário saber a origem e evolução histórica dos direitos e garantias que a Constituição Federal, de 1988, disciplina em seu ordenamento.

Alguns doutrinadores afirmam que os direitos fundamentais e garantias fundamentais passaram a existir primeiramente no Ordenamento Constitucional Inglês. No entanto, outros afirmam que o surgimento desses direitos se deu a partir da Revolução Francesa.

Nesse sentido, de acordo com Paulo e Alexandrino, passamos a expor: 
Alguns autores apontam como marco inicial dos direitos fundamentais a Magna Carta inglesa (1215). Os direitos ali estabelecidos, entretanto, não visavam garantir uma esfera irredutível de liberdades aos indivíduos em geral, mas sim, essencialmente, assegurar poder político aos barões mediante dos poderes do rei. (2009, p. 89)

A dignidade da pessoa humana é um direito estabelecido pela história, sendo que a Constituição Federal preceitua-o como princípio fundamental, que resguarda a materialização dos demais direitos fundamentais, protegendo, assim, o ser humano de qualquer situação de menosprezo. É, ainda, considerado como valor constitucional supremo o núcleo axiológico da Carta Magna.

Paulo e Alexandrino lembram que

A positivação dos direitos fundamentais deu se a partir da Revolução Francesa, com a Declaração dos Direitos do homem (Déclaration des Droits de I'Homme et du Citoyen em 1789) e das declarações de direitos formulados pelos Estados Americanos , ao firmarem sua independência em relação à Inglaterra (Virginia Bill DF Rghts, em 1776). Originam-se, assim, as Constituições liberais dos Estados ocidentais dos séculos XVII e XIX. (2009, p. 89)

Os direitos fundamentais surgiram com a finalidade de descentralizar o poder soberano do Estado, garantindo aos indivíduos autonomia para o seu direito de ser livre, perante a atuação do Estado.

Nesse sentido, Paulo e Alexandrino ainda são sábios dizeres dos constitucionalistas:

Os primeiros direitos fundamentais têm o seu surgimento ligado à necessidade de se impor limites e controles aos atos praticados pelos estados e suas autoridades constituídas. Nasceram, pois,como uma proteção á liberdade do indivíduo frente a ingerência abusiva do Estado. [...] Somente no século $X X$, com o reconhecimento dos direitos fundamentais de segunda dimensãodireitos, culturais e econômicos -, os direitos fundamentais passam a ter feição positiva, isto é, passaram a exigir também, a atuação comissiva do Estado, prestações estatais em favor do bem-estar dos indivíduos. (2009, p. 90)

Sobre o conceito de garantias constitucionais, estes se distinguem dos direitos fundamentais apesar de se interligarem, uma vez que as garantias constitucionais dão concretude aos direitos fundamentais, ou seja, a efetiva aplicação.

Na mesma linha de raciocínio, Paulo e Alexandrino ainda prelecionam que

As garantias fundamentais são estabelecidas pelo texto constitucional como instrumentos de proteção dos direitos fundamentais. As garantias possibilitam que os indivíduos façam valer, frente ao Estado, os seus direitos fundamentais Assim, ao direito á vida corresponde a garantia de vedação á pena de morte; ao 
direito a liberdade de locomoção corresponde a garantia do habbeas corpus; ao direito a liberdade de manifestação de pensamento, a garantia da proibição de censura etc. (2009, p. 91)

princípio da dignidade da pessoa humana teve marco inicial a partir do reconhecimento dos direitos e garantias fundamentais no ordenamento constitucional brasileiro.

A Constituição Federal Brasileira, de 1988, trata logo no seu primeiro título dos princípios fundamentais que norteiam o Estado e a Nação Brasileira, de forma a descentralizar o poder estatal e a limitá-lo, e ainda, de garantir a supremacia dos direitos fundamentais aos particulares.

Ademais, a Constituição Brasileira traz, em seus artigos $1^{\circ}$ a $5^{\circ}$, as chamadas garantias fundamentais e os direitos individuais, denominados "Princípios Constitucionais", que, por vezes, são desrespeitados pelo Estado no exercício jurisdicional de seu poder de punir.

Logo no artigo $\mathrm{I}^{\circ}$, inciso III, da Constituição Federal, é tratado acerca da dignidade da pessoa humana, vejamos:

Art. $1^{\circ}$ A República Federativa do Brasil, formada pela união indissolúvel dos Estados e Municípios e do Distrito Federal, constitui o Estado Democrático de Direito e tem como fundamentos:

I-soberania;

II - a cidadania;

III - a dignidade da pessoa humana; (grifo nosso)

$\mathrm{IV}$ - os valores sociais do trabalho e da livre iniciativa;

$\checkmark$-o pluralismo político; (CF/88)

O ser humano, na organização social, é o fundamento da existência de todas as demais organizações. Isso porque, de acordo com Marcelo Paulo e Vicente Alexandrino, é assegurado que,

De um modo geral, esses princípios consubstanciam o reconhecimento da soberania, no plano internacional, como elemento igualador dos Estados, além de reconhecer, também nesse âmbito o ser humano como centro das preocupações da nossa República. A dignidade da pessoa humana como fundamento da República Federativa do Brasil consagra, desde logo, nosso Estado como uma organização centrada no ser humano, e não em qualquer outro referencial. A razão de ser do Estado brasileiro, não se finda na propriedade, em classes em corporações, em organizações religiosas, tampouco no próprio Estado (como ocorre nos regimes totalitários), mas sim na pessoa humana. Na feliz síntese de Alexandre Moraes, "esse fundamento afasta a ideia de predomínio das concepções transpessoalistas de Estado e Nação, em detrimento da liberdade individual". São vários os valores constitucionais que 
decorrem diretamente da ideia de dignidade da pessoa humana, tais como, dentre outros, o direito á vida, á intimidade, à honra e à imagem. (2009, p. 86)

Fica evidente que diversos princípios dispostos na Constituição Federal amparam o ser humano como centro de todas as atenções da nossa República. A dignidade da pessoa humana é um dos fundamentos da República Federativa do Brasil.

Nesse sentido, Jussara Jacintho afirma que,

Assim, a dignidade como valor supremo a orientar a interpretação constitucional é imponderável, insuscetível de ceder diante do caso concreto, a outro direito qualquer que the seja. A dignidade não pode ser relativizada diante de outro direito. A interferência no núcleo da dignidade humana não é coberta pela liberdade de expressão. (2006, p. 164)

A Carta Magna preconiza a pessoa humana como a razão de ser do Estado Brasileiro, porque consagra a dignidade da pessoa humana como princípio máximo no artigo $5^{\circ}$, inciso III.

Art. $5^{\circ}$ Todos são iguais perante a lei, sem distinção de qualquer natureza, garantindo-se aos brasileiros e aos estrangeiros residentes no País a inviolabilidade do direito à vida, à liberdade, à igualdade, à segurança e à propriedade, nos termos seguintes:

$[\ldots]$

III - ninguém será submetido a tortura nem a tratamento desumano ou degradante; (CF/I 988)

Tal artigo ampara a garantia de respeito e tratamento digno ao indivíduo, garantindo ainda a sua liberdade individual, a igualdade dos seres humanos perante o poder estatal com o devido respeito aos demais direitos que decorram do princípio da dignidade da pessoa humana.

Paulo e Alexandrino mostram que

A dignidade da pessoa humana estabelece uma unidade aos direitos e garantias fundamentais, inerentes à personalidade humana. Assevera ainda que a dignidade seja um valor espiritual e moral próprio da pessoa, que se manifesta na autodeterminação consciente e responsável da própria vida e que traz consigo a pretensão ao respeito por parte das demais pessoas, constituindo-se um mínimoinvulnerável que todo estatuto jurídico deve assegurar. (2009, p. 87)

De outro modo, a prisão processual é vista como exceção no ordenamento jurídico brasileiro, de forma a implicar o reconhecimento da dignidade da pessoa humana. Portanto, diante dessa excepcionalidade, deve haver motivação expressa que indique no que consiste o fundamento da prisão. 


\subsubsection{Princípio da humanidade da pena}

Nessa pequena explanação sobre o princípio da humanidade da pena, interessa citar os ensinamentos de Nogueira (2008) quando menciona: "Conforme sua própria conceituação, deriva de um dos fundamentos da República Federativa do Brasil, qual seja, a dignidade da pessoa humana".

Seguindo os dizeres apontados, nota-se que,

Prevista no artigo $1^{\circ}$, III da Constituição Federal a dignidade da pessoa humana classifica-se como um princípio relativo ao regime político e caracteriza-se como um valor supremo que abrange todos os direitos fundamentais do homem, desde o seu direito primário à vida. Tal princípio deve incidir não só em relação aos direitos fundamentais da pessoa, mas sim deverá incidir sobre as demais disposições da Constituição Federal, tais como direitos sociais e ordem econômica, vez que se apresenta como base de garantia da própria existência humana. (NOGUEIRA, 2008)

A princípio insta mostrar que o princípio da humanidade da pena busca assento não só na Lei Maior, mas também nos tratados internacionais e, claro, na própria Lei de Execução Penal (LEP).

De acordo com o que está disposto na Constituição Federal, de 1988, o princípio da humanidade da pena encontra abrigo no artigo $4^{\circ}$, II, no qual se fixou o princípio da prevalência dos direitos humanos nas relações internacionais do Brasil, a saber:

Art. $4^{\circ}$ A República Federativa do Brasil rege-se nas suas relações internacionais pelos seguintes princípios: I - [...]; || - prevalência dos direitos humanos.

Verifica-se ainda, na Lei Maior, a exaltação do princípio da humanidade da pena dentre os direitos fundamentais da pessoa humana, em disposições do artigo $5^{\circ}$, incisos III, XLV, XLVI, XLVII, XLVIII e XLIX:

Segundo Nogueira, "No que se refere ao previsto no inciso XLVII, observa-se que o constituinte proibiu expressamente as penas de morte, de trabalhos forçados, de caráter perpétuo, de trabalhos forçados, de banimento e as cruéis" (NOGUEIRA, 2008).

\subsubsection{Princípio da vedação ao excesso de execução}

Este princípio decorre do princípio do respeito à coisa julgada, que tem assento constitucional (art. $5^{\circ}$, inciso XXXVI, da Carta Magna), in verbis:

Art. $5^{\circ}$ Todos são iguais perante a lei, [...]XXXVI - a lei não prejudicará o direito adquirido, o ato jurídico perfeito e a coisa julgada. 
Nesse sentido, de acordo com o disposto no art. $1^{\circ}$ da LEP, a execução penal tem por escopo concretizar as disposições da sentença ou decisão criminal, não podendo se distanciar sob pena de afrontar o título executivo da autoridade da coisa julgada.

Fernando Vernice dos Anjos assegura que

A LEP ainda dispõe, no art. 185, que haverá excesso de execução sempre que algum ato realizado no bojo do processo executivo for praticado fora dos limites fixados na sentença, em normas legais ou regulamentares. Em consonância com 0 art. $3^{\circ}$ da LEP, percebe-se que haverá excesso de execução sempre que for atingido algum direito do condenado não restringido pela sentença condenatória ou pela lei. Interessante constatação sobre o princípio em questão é feita por Gustavo Octaviano Diniz Junqueira: "as consequências de tal princípio são óbvias na teoria geral do processo, mas mais eficazes no processo civil, quando a execução a maior causa escândalo e, invariavelmente, é afastada desde logo pela totalidade dos tribunais. Incrível que o panorama não seja o mesmo na seara criminal, quando o cumprimento de pena em regime mais grave que aquele autorizado pela sentença não causa o mesmo escândalo, e subsistam ainda posições jurisprudenciais (já minoritárias) ratificando que a violência estatal efetivada seja maior que a disposta na sentença". (201 I , online)

Portanto, sempre que a execução for além do que é aceito pelo título executivo corporificado pela sentença, vulnerando com isso a coisa julgada e provocando excesso de execução, necessita ser corrigida logo em seguida pela atuação do próprio Judiciário.

Contudo, segundo os dizeres de Anjos, "a jurisprudência ainda não considera como excesso de execução a pena de privação de liberdade cumprida em condições desumanas que, como já visto, viola também o princípio da humanidade das penas" (20I I, online).

Somente quando a escassez de liberdade e alguma outra modalidade de pena acatarem estritamente os limites de restrição de direitos atribuída na sentença, que deve essencialmente refletir os limites da lei (princípio da legalidade das penas), pode-se falar em efetivo respeito ao princípio da vedação ao excesso de execução.

\subsubsection{Princípio da personalidade ou intranscedência}

O princípio da personalidade ou intranscendência "É aquele pelo qual a pena só pode ser dirigida contra o infrator, não podendo transbordar suas fronteiras aflitivas para qualquer outra pessoa" (ANJOS, 201 I , online).

De outra forma, de acordo com René Ariel Dotti citado por Anjos, "sendo a pena o efeito de uma causa determinada e consistente no delito censurável na pessoa de seu autor, somente contra este deve recair a sanção" (DOTTI apud ANJOS, 20 I I, online).

Justifica-se tal princípio pela reflexão de responsabilidade pessoal do autor pelo seu 
fato típico, ilícito e culpável. A personalidade da pena possui guarida na Constituição Federal, de 1988, que, em seu art. $5^{\circ}, \mathrm{XLV}$, sobre o assunto bem mostra Anjos quando diz

"que nenhuma pena passará da pessoa do condenado, podendo a obrigação de reparar o dano e a decretação do perdimento de bens ser estendidas aos sucessores e contra eles executadas, até o limite do valor do patrimônio transferido" (ANJOS, 201 I, online).

Com propriedade Anjos lembra que

Trata-se de um princípio simples de ser explicado e abstratamente aplicado. Qualquer regime democrático repudia as antigas sanções de infâmia ou confisco contra a família do criminoso. No entanto, é sabido que qualquer pena e, em especial, a de prisão, afeta o círculo de pessoas próximas ao condenado. Famílias ficam privadas de pais e de mães que, encarcerados, não podem provê-las, ocorrendo uma verdadeira "transferência da pena." Raúl Cervini ainda adverte sobre o sério problema de "generalização" e "contágio de rótulos", pelo qual a sociedade tende a discriminar a família do apenado pelo simples fato de um familiar ter cometido um crime, numa espécie de "pena de infâmia" sem previsão legal. (201 I, online)

Nesse sentido, medidas devem ser tomadas para suavizar a imagem que a punição penal acende sobre o círculo que envolve o apenado. No ordenamento jurídico pátrio está previsto o auxílio-reclusão como benefício previdenciário com essa finalidade (art. 80 da Lein 0.213 , de 1991).

Art. 80. $\bigcirc$ auxílio-reclusão será devido, nas mesmas condições da pensão por morte, aos dependentes do segurado recolhido à prisão, que não receber remuneração da empresa nem estiver em gozo de auxílio-doença, de aposentadoria ou de abono de permanência em serviço.

Parágrafo único. O requerimento do auxílio-reclusão deverá ser instruído com certidão do efetivo recolhimento à prisão, sendo obrigatória, para a manutenção do benefício, a apresentação de declaração de permanência na condição de presidiário.

Já no plano da execução penal, o direito à visita e as medidas pautadas à mulher presidiária, estando gestante ou mesmo amamentando, a quem devem ser direcionados direitos exclusivos para o crescimento sadio dos seus filhos, igualmente podem ser mencionados.

\section{CONSIDERAÇÕES FINAIS}


A Lei de Execução Penal (LEP), Lei n 7.210, de II de julho de 1984, é atualmente uma norma dotada de excelência do ordenamento jurídico brasileiro. Em que pese ter sido editada ainda em meados da década de 1980 e, consequentemente, anterior à Constituição Federal, de 1988, esta legislação promoveu inovações significativas, mantidas até a presente data.

Há de se reconhecer que o sistema prisional pátrio nem sequer conseguiu adequarse à totalidade de seus elementos basilares, o que ainda permite verificar a existência de contrastes: entre o que a lei em comento descreve e o que na prática acontece.

A Constituição Federal, de 1988, assegura garantias fundamentais aos condenados e àqueles que aguardam, detidos, sua sentença. Desta sorte, a execução penal adota alguns princípios constitucionais e específicos do Direito Penal, como: legalidade, isonomia, personalização da pena, jurisdicionalidade, devido processo legal, contraditório e ampla defesa. Além desses, adota outros princípios, quais sejam, da segurança, da paz e da ordem social e da ressocialização.

O Código Penal Brasileiro estabelece, em seu art. 59, que a pena deverá atender a dois critérios: um voltado à repressão e outro à prevenção, o que por sua vez acaba impondo o dever de ressocialização.

Sabe-se que o sistema penitenciário do Brasil está falido há tempos. Percebem-se a situação precária e as condições, na maioria das vezes, subumanas em que os encarcerados se encontram hoje. Sem falar na violência crescente nas prisões brasileiras.

A superlotação vivenciada hoje remete à lembrança de que os presídios no Brasil não passam de meros depósitos de pessoas, trazendo consigo a violência moral, sexual e física entre os detentos; assim no encarceramento feminino à luz dos direitos humanos existem muitas falhas que devem ser amparadas e observadas pelo legislador.

\section{REFERÊNCIAS}

ANJOS, Fernando Vernice dos. Princípios limitadores da execução penal. (20 I I). D i s p o n í ve I e m : <http://www.vepema.com.br/vepema/cariboost_files/Princ_C3_ADpios_20limitador es_20da_20execu_C3_A7_C3_A3o_20penal.pdf $>$. Acesso em 9 abr. $20 \overline{1} 6$.

BARREIROS, Yvana Savedra de Andrade. A ilegitimidade da pena privativa de liberdade à luz dos fins teóricos da pena no sistema jurídico brasileiro. Jus Navigandi, Teresina, ano 12, n. 1798, 3 jun. 2008. Disponível em: <http://jus2.uol.com.br/doutrina/texto.asp?id=| | 332>. Acesso em 29 jun. 2016.

BRASIL. Constituição da República Federativa do Brasil de 1988. Presidência da República, Casa Civil, Subchefia para Assuntos Jurídicos, Brasília. Disponível em: 
<http://www.planalto.gov.br/ccivil_03/constituicao/constitui\%C3\%A7ao.htm> .

Lei n 7.210, de II de julho de 1984: Lei de Execução Penal. Presidência da República, Casa Civil, Subchefia para Assuntos Jurídicos, Brasília. Disponível em: <http://www.planalto.gov.br/ccivil/leis/L7210.htm>.

. Lei n 8.213, de 24 de julho de 1991. Presidência da República, Casa Civil, Subchefia para Assuntos Jurídicos, Brasília. Disponível em: $<$ http://www.planalto.gov.br/ccivil/leis/L82 I3cons.htm>

BECCARIA, Cesare Bosesana Marchesi de. Dos delitos e das penas. 4. ed. São Paulo: Revista dos Tribunais, 2010

BITENCOURT, Cezar Roberto. Falência da pena de prisão: causas e alternativas. 3. ed. São Paulo: Saraiva, 2004.

BOSCHI, José Antonio Paganella. Das penas e seus critérios de aplicação. 4. ed. Porto Alegre: Livraria do Advogado, 2008

CARDOSO, Fraciele da Silva. Penas e medidas alternativas: análise da efetividade de sua aplicação. São Paulo: Método, 2004.

CAPEZ, Fernando. Curso de processo penal. 14. ed, rev. e atual. São Paulo: Saraiva, 2009.

COSTA NETO, Nilo de Siqueira. Ressocialização do preso: falência do sistema penitenciário. Revista Jus Navigandi, Teresina, ano 18, n. 3560, 31 mar. 2013. Disponível em: <http://jus.com.br/artigos/24073>. Acesso em 27 jun. 2016.

DOTTI, René Ariel. Bases alternativas para o sistema de penas. 2. ed. São Paulo: Revistas dos Tribunais, 1998. Disponível em: <http://jusvi.com/artigos/2068> . Acesso em $1^{\circ}$ maio 2015.

ESPINOZA, Olga. A mulher encarcerada em face do poder punitivo. São Paulo: IBCCrim, 2004.

FOLHA DE SÃO PAULO. Presas são vítimas de abuso em 5 Estados, diz relatório. Disponível em: <http://wwwl.folha.uol.com.br/fsp/cotidian/ff26| | 20070 I.htm>. Acesso em 2 jun. 2016. 
FOUCAULT, Michel. Vigiar e punir. 7. ed. Petrópolis: Vozes, 2010.

FRANCO, Alberto Silva. Crimes hediondos. 5. ed. São Paulo: Revista dos Tribunais, 2005.

GRECO, Rogério. Curso de direito penal. I I . ed. Rio de Janeiro: Impetus, 2009.

JACINTHO, Jussara. Dignidade humana: princípio constitucional. Curitiba: Juruá, 2006.

KLOCH, Henrique; MOTTA, Ivan Dias da. O sistema prisional e os direitos da personalidade do apenado com fins de res(socialização). Porto Alegre: Verbo Jurídico, 2008.

LIMA, Rosineide pereira de. SEJUS e sistema penitenciário do amazonas: contribuindo para a segurança pública e ressocialização de presos. Manaus: Centro Universitário Nilton Lins, 2008.

MARQUES, José Frederico. Curso de direito penal: propedêutica penal e norma penal. São Paulo: Saraiva, 2006.

MISCIASCl, Elizabeth. Como surgiram os cárceres. (20/4). Disponível em: $<$ http://www.eunanet.net/beth/revistazap/topicos/inicioprisoesl.htm>. Acesso em 9 jun. 2016.

MIRABETE, Júlio Fabrini. Execução penal, comentários à Lei 7.210, de II.7.84. | । ed. São Paulo: Atlas, 2004.

Processo penal interpretado. 18. ed. São Paulo: Atlas, 2007.

NIETZSCHE, F. Sämtliche Werke. Kritische Studienausgabe. München/Berlin/ New York, DtvMalter de Gruyter \& Co., I 5 vols, 1988.

NOGUEIRA, Danielle Christine Barros. O princípio da humanidade da pena. Disponível em: < http://www.lfg.com.br. (2008)> . Acesso em I 0 abr. 201 I.

NUNES, Luiz Rizzatto. O princípio constitucional da dignidade da pessoa humana. São Paulo: Saraiva, 2002.

OLIVEIRA, Odete M. Prisão: um paradoxo social. 3. ed. Florianópolis: UFSC, 2003. 
PASSETI, Gabriel. Ilha grande, ilha cárcere. (20|4). Disponível em: <http://www.klepsidra.net/klepsidra I 7/ilhagrande.htm>. Acesso em 9 jun. 2016.

PAULO, Marcelo; ALEXANDRINO, Vicente. Princípios, direitos e garantias fundamentais. 4. ed., revista e atualizada. Rio de Janeiro: Forense; São Paulo: Método, 2009.

PORTO, Roberto. Crime organizado e sistema prisional. São Paulo, Ática, 2008.

SANTOS, Priscila. A gênese e as prisões. (2007). Disponível em: <http://obviousmag.org/archives/2007/06/panoptico_a_gen.html>. Acesso em 10 jun. 2016

SILVA, Patrícia Gomes da. Ressocialização do setenciado. Governador Valadares: Univale, 2008.

TOURINHO FILHO, Fernando da Costa. Processo penal. Vol. 3, 26. ed. ver., atual. e aument. São Paulo: Saraiva, 2004.

Recebido em: 26/09/2016 Aprovado em: 03/10/2016 
